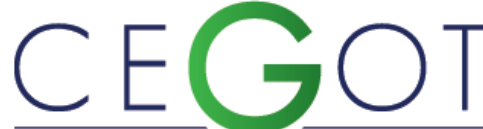

Centro de Estudos de Geografia e Ordenamento do Território
FerRetto, Diego

Universidade Paulista

Rua Antônio Macedo, 505 CEP 03087-010, São Paulo, Brasil

diego.ferretto@docente.unip.br

\title{
Produção imobiliária e reestruturação intraurbana em Passo Fundo - RS
}

Real estate production and intra-urban restructuring in Passo Fundo - RS

Referência: Ferretto, Diego (2021). Produção imobiliária e reestruturação intraurbana em Passo Fundo - RS. Revista de Geografia e Ordenamento do Território (GOT), n. 21 (Junho). Centro de Estudos de Geografia e Ordenamento do Território, p. 263-289, dx.doi.org/ 10.17127/got/2021.21.011

\section{RESUMO}

Este artigo tem por objetivo discutir a disseminação de condomínios horizontais e bairros planejados na cidade de Passo Fundo - RS, na década de 2010. Parte-se da hipótese que os novos produtos imobiliários redefinem os processos de segregação socioespacial, evidenciando a dispersão das classes de média e alta renda por áreas periféricas, tradicionalmente ocupadas pela população de baixa renda. A ressignificação da periferia denota a complexificação da estrutura socioespacial intraurbana, indicando a emergência de novos padrões de segregação socioespacial, sobrepostos ao tradicional modelo centroperiferia, constituído no século XX. Nesse contexto, defende-se ser possível reconhecer processos de reestruturação em curso, caracterizados por rupturas significativas com as lógicas precedentes de produção do espaço intraurbano.

Palavras-chave: Passo Fundo; Produção imobiliária; Reestruturação intraurbana; Segregação socioespacial.

\section{ABSTRACT}

This article aims to discuss the spread of horizontal condominiums and planned neighborhoods in the city of Passo Fundo - RS, in the decade of 2010. It is assumed that the new real estate products redefine the processes of socio-spatial segregation, showing the dispersion of the classes of middle and high income for peripheral areas, traditionally occupied by the low-income population. The reframing of the periphery denotes the complexification of the intra-urban socio-spatial structure, indicating the emergence of new patterns of socio-spatial segregation, superimposed on the traditional center-periphery model, constituted in the 20th century. In this context, it is argued that it is possible to recognize ongoing common processes, characterized by significant disruptions with the previous logic of production of intra-urban space.

Keywords: Passo Fundo; Real estate production; intra-urban restructuring; Socio-spatial segregation. 


\section{Introdução}

Localizada na porção norte do estado do Rio Grande do Sul, com população estimada em 203 mil habitantes (IBGE, 2019), Passo Fundo caracteriza-se como uma das principais cidades médias gaúchas, assumindo a definição de cidade média de Sposito (2007) como aquelas que desempenham papéis de intermediação na rede urbana, cuja identificação extrapola o tamanho demográfico. Segundo o estudo de Regiões de Influência (REGIC, 2008) do IBGE, Passo Fundo é classificada como capital regional B, mesmo nível hierárquico das cidades de Caxias do Sul e Santa Maria, abaixo somente da metrópole, Porto Alegre.

Sobarzo (2010) define Passo Fundo como cidade média com funções comerciais, de serviços e de apoio ao agronegócio, argumentando que a cidade estabelece simultaneamente relações horizontais com a região, a partir da oferta de comércio e serviços especializados, sobretudo nas áreas de saúde e educação superior, e relações verticais, que extrapolam a região, como cidade de apoio ao agronegócio, inserindo-se em circuitos internacionais da produção de alimentos.

Segundo Corrêa (2007), a identificação de uma cidade média depende de uma combinação específica de três fatores: tamanho demográfico, funções urbanas e organização do espaço intraurbano. Nesse texto, privilegia-se a escala de análise intraurbana, tendo por objetivo discutir a emergência de processos de reestruturação intraurbana na cidade de Passo Fundo, em curso na década de 2010. A noção de reestruturação é mobilizada para indicar momentos de ruptura com as lógicas precedentes de produção do espaço intraurbano. Sposito e Góes (2013, p. 278) explicam que

\footnotetext{
tomando-se como referência os processos de estruturação espacial sempre em curso, podemos reconhecer momentos em que as rupturas são expressas pela redefinição mais profunda de lógicas que orientam a produção do espaço urbano e as formas de apropriação e uso desses espaços, cabendo, então, a adoção da expressão 'reestruturação' para tal.
}

Parte-se da hipótese que a disseminação de novos produtos imobiliários, condomínios fechados horizontais e bairros planejados, ressignificam os processos de segregação socioespacial, evidenciando a emergência da dispersão das classes de média e alta renda por áreas periféricas, tradicionalmente ocupadas pela população de baixa renda. 
Mesmo presentes em parcela significativa das grandes cidades e cidades médias, os condomínios horizontais e bairros planejados, assim como os shopping centers, no contexto de Passo Fundo, representam inovações espaciais, nos termos de Corrêa (2010, p.150), instrumentais à reprodução capitalista e à formação de setores seletivos apropriados pela classe média e pelas elites; ideologicamente, representam o novo, e através de estratégias publicitárias, contribuem para a obsolescência das formas urbanas precedentes.

Do ponto de vista teórico-metodológico, a discussão se âncora na denominada perspectiva teórica da produção do espaço, abordagem de matriz marxista inaugurada por Henri Lefebvre, na década de 1970, que ao assumir o espaço como um produto social, admite que no sistema capitalista, este assume papel determinante, se manifestando de forma polivalente, pois constitui um produto que se utiliza, se consome, além de ser também um meio de produção. Segundo Carlos (2015), essa perspectiva permite ultrapassar a compreensão objetiva do espaço, como localização dos fenômenos, para percebê-lo como produção social, evoluindo da compreensão da "organização do espaço" à "produção do espaço", tendo o materialismo histórico como orientação teórica, e o método dialético como caminho de pesquisa que permite pensar o espaço como mercadoria, inserido na totalidade da produção social capitalista. No capitalismo, a produção do espaço se traduz na apropriação privada de um produto socialmente produzido, cujo acesso é mediado pelo mercado imobiliário, evidenciando o domínio do valor de uso ao valor de troca.

A produção do espaço envolve processos, agentes e formas espaciais concretos. Segundo Corrêa (2013), os agentes sociais (históricos) envolvidos na produção do espaço urbano podem ser classificados em cinco grupos, dos proprietários dos meios de produção, dos proprietários fundiários, dos promotores imobiliários, do Estado e dos grupos sociais excluídos. Dentre as formas e processos espaciais, o autor destaca a centralização e áreas centrais; a descentralização e os núcleos secundários; a coesão e áreas especializadas; a segregação e áreas sociais; a inércia e áreas cristalizadas.

O recorte estabelecido neste texto enfatiza a atuação de um agente social específico, o setor imobiliário, na produção de formas espaciais, os condomínios horizontais de alta renda e os bairros planejados, que se traduzem em processos de segregação socioespacial. O setor imobiliário é abordado genericamente nesse estudo, englobando os promotores imobiliários e os proprietários fundiários, que embora possam ou não atuar conjuntamente, 
sempre dependem da anuência ou colaboração Estado. Já a segregação socioespacial é assumida como um dos fundamentos da produção do espaço urbano, em sua dimensão negativa, a partir da propriedade privada. Empiricamente, entende-se por segregação socioespacial algum nível (ou grau) de separação ou de afastamento físico de um grupo social relativamente homogêneo em relação aos demais (Marques, 2005; Sabatini, 2003). Dentre as premissas metodológicas relacionadas ao conceito de segregação, destaca-se sua natureza espacial, que exige a adoção de uma escala geográfica de análise, assim como seu caráter processual, que pressupõe a adoção de um recorte temporal significativo de análise (Marques, 2005; Sposito, 2013). Assim, supera-se a interpretação da segregação restrita a um reflexo da estrutura social, enfatizando seu papel ativo na produção do espaço urbano, como processo que condiciona a vida cotidiana e as práticas sociais, assim como seu caráter instrumental à dominação social, traduzida em privilégios locacionais para as elites (Sabatini, 2003; Villaça, 2001).

A partir dessas premissas, a temática aqui abordada tem por objetivo contribuir com 0 profícuo debate no campo dos estudos urbanos, voltado à compreensão dos processos de reestruturação intraurbana e dos novos padrões espaciais de segregação em cidades médias, especificamente a partir da análise da disseminação de condomínios horizontais e de bairros planejados. Embora a revisão da literatura demonstre a reprodução indiscriminada desses produtos imobiliários a serviço da acumulação capitalista, este texto pretende subsidiar também a análise comparativa, perspectiva fundamental ao reconhecimento das especificidades e similaridades entre cidades médias. Nesse sentido, valoriza-se a dimensão histórica do processo de urbanização de Passo Fundo e busca-se ultrapassar a etapa descritiva, de denúncia, em direção à compreensão das repercussões dos novos empreendimentos imobiliários na estrutura intraurbana, apontando em que medida são determinantes a novas lógicas de produção do espaço urbano.

Como referencial da literatura especializada sobre a temática, que se avoluma nas últimas décadas, é possível destacar, sobretudo pelo rigor teórico-metodológico, a produção vinculada à RECIME (Rede de Pesquisadores sobre Cidades Médias), especialmente na série de publicações denominada Agentes econômicos e reestruturação urbana e regional, organizadas por Sposito, Soares e Ribeiro (2010, 2010a, 2012, 2013, 2015) e Sposito e Maia (2016), em que abordagens multiescalares oferecem diferentes enfoques analíticos, dentre 
os quais, na escala intraurbana, os processos de segregação socioespacial figuram em destaque, conforme demonstrado para as cidades de Passo Fundo e Mossoró (2010), Tandil e Uberlândia (2010), Chillán e Marília (2012), Campina Grande e Londrina (2013), Marabá e Los Ángeles (2015) e Dourados e Chapecó (2016). A abordagem sobre Passo Fundo, que compõe uma das publicações, de autoria do geógrafo Oscar Sobarzo, além de qualificar seus atributos de cidade média, apresenta aspectos de sua estrutura socioespacial que enunciam os processos de segregação.

Considerando a produção regional, focada no estado do Rio Grande do Sul, há diversos trabalhos dedicados à compreensão dos processos de segregação socioespacial em cidades médias gaúchas. Nesse rol inclui-se nossa contribuição, que subsidia em partes a produção deste artigo, voltada à análise comparada dos padrões de segregação nas quatro principais cidades médias gaúchas, Caxias do Sul, Passo Fundo, Pelotas e Santa Maria (Autor, 2018). Sobre Santa Maria, sobressai-se ainda a pesquisa de Rocha (2011) acerca do padrão locacional da estrutura social; sobre Pelotas, têm relevância a pesquisa de Vieira (2005), que aborda a fragmentação socioespacial da cidade. Voltados especificamente à temática dos condomínios fechados, pode-se mencionar os trabalhos de Souza (2013), acerca da expansão de condomínios horizontais no litoral norte do estado, Pohl (2015), centrada no caso de Santa Cruz do Sul, e Leite (2013), que tem por objeto o aglomerado urbano Canela Gramado, na serra gaúcha.

Por fim, é importante ressaltar uma referência fundamental nesse campo de pesquisa, o trabalho de Sposito e Góes (2013), intitulado Espaços fechados e cidades: insegurança urbana e fragmentação socioespacial, em que as autoras associam a disseminação de condomínios horizontais periféricos em cidades médias paulistas (Marília, Presidente Prudente, São Carlos) a processos de reestruturação urbana, e defendem estar em curso, nessas cidades, a complexificação dos processos de segregação em direção à fragmentação socioespacial, processo que extrapola o uso residencial, envolve a formação de novas centralidades urbanas e representa maior fragmentação social, caracterizada pela proximidade física entre ricos e pobres, nas áreas periféricas, porém com maior distanciamento social, garantido pelos muros.

Do ponto de vista formal, o texto se organiza em duas partes: primeiro, a partir de um recuo histórico, estabelece-se um panorama acerca dos processos de formação e estruturação 
intraurbana de Passo Fundo ao longo dos séculos XIX e XX, período caracterizado pela expansão periférica e pela constituição do padrão de segregação no modelo centroperiferia; a segunda parte do texto avalia os processos recentes de reestruturação intraurbana em curso, apontando significativas rupturas nas lógicas de produção do espaço urbano, a partir da implantação de condomínios fechados horizontais e bairros planejados nas periferias.

\section{Formação e estruturação intraurbana}

Os O processo de estruturação intraurbana de Passo Fundo pode ser sintetizado em três períodos, relacionados à sua base econômica, dinâmicas demográficas e estrutura socioespacial (Ferretto, 2018). O mapa de expansão urbana (figura 1) subsidia a compreensão desses períodos em sua dimensão espacial.

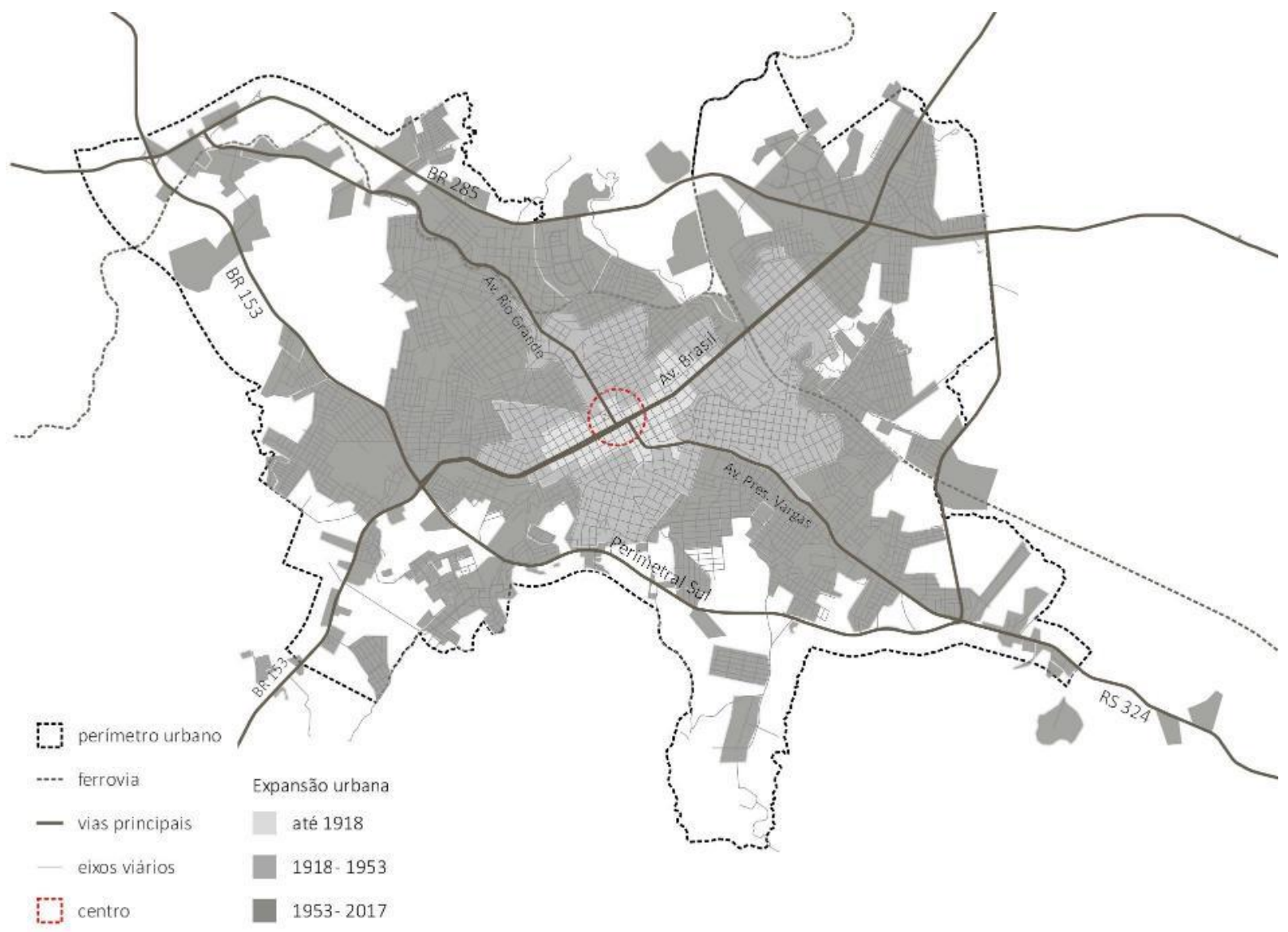

Passo Fundo: expansão urbana

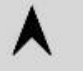

Fonte: daboraçăo própria Base de dados: Ferretto 12012,2018

Figura 1 - Passo Fundo: expansão urbana Fonte: Elaborado pelo autor, com base em Ferretto $(2012,2018)$ 
O primeiro período, de formação urbana, remete ao século XIX, no contexto da sociedade pecuarista, anterior à colonização estrangeira, baseando-se no transporte de animais muares para a feira de Sorocaba, exportação de erva-mate e de pedra ágata (Dal'Moro e Ruckert, 2004, p. 31). O povoado, elevado à categoria de município em 1857, apresenta uma restrita ocupação linear ao longo do antigo caminho das tropas, atual Avenida Brasil. Em 1890, a população é de aproximadamente 21 mil habitantes. Nesse período, de ocupação compacta, é difícil identificar segregações socioespaciais, no entanto, pode-se pressupor padrões de diferenciação socioespacial (Sposito, 2013), como uma etapa anterior à segregação, caracterizada pelas diferentes tipologias residenciais, tamanhos de lotes e oferta de infraestrutura urbana. É sabido, no entanto, que na Avenida Brasil concentram-se as residências das famílias mais abastadas.

O segundo período, que se inicia no final do século XIX e se estende até a metade do século $X X$, se define pelo crescimento econômico e incremento demográfico, no contexto de transição da agricultura de subsistência para a agricultura comercial desenvolvida através de subsídio federal e do trabalho de imigrantes europeus, realizado em pequenas propriedades. Fundam-se colônias europeias ao longo da ferrovia, o município efetiva-se como polo de desenvolvimento para a região e surge a figura do colono, pequeno agricultor imigrante que recebe incentivos do governo para a produção de alimentos e aquisição de terras. A produção de trigo, subsidiada pelo governo federal, torna-se a primeira cultura da região, fornecendo as bases para uma agricultura comercial (Tedesco e Sander, 2005).

Em 1920, a população chega a 65 mil habitantes, e em 1950, já ultrapassa os 100 mil. Espacialmente, observa-se o crescimento expressivo da mancha urbana, com a formação dos primeiros bairros e vilas populares periféricos, fato determinado pela promoção imobiliária de loteamentos de caráter rentista. A implantação da ferrovia e sobretudo da estação ferroviária caracterizam a mudança de direção da expansão urbana, que ocorria no sentido oeste (ao longo do caminho das Tropas, sentido Boqueirão) para sudeste; o antigo centro se desloca o entorno da estação, sem diminuir, no entanto, a importância da Avenida Brasil, nesse momento denominada Rua do Comércio, como principal eixo estruturador da ocupação. A cidade cresce horizontalmente a partir do loteamento de grandes propriedades que a cercavam. Dessa forma, acrescentam-se rupturas e distanciamentos mais significativos entre as classes sociais (trabalhadores urbanos, comerciantes, colonos) 
produzindo-se uma clara diferenciação entre o centro, dotado de infraestrutura e equipamentos, e a periferia, frequentemente desatendida em todos os sentidos, emerge assim o padrão de segregação centro-periferia.

O terceiro período abrange a segunda metade do século XX e se estende aos dias de hoje, é caracterizado pelo processo de reestruturação produtiva da agricultura, com a adoção da monocultura (trigo e soja especialmente) praticada em grandes propriedades mecanizadas. O município passa a se inserir em circuitos econômicos mais amplos, atuando na exportação de soja, máquinas agrícolas e outros produtos do setor.

O processo de urbanização se intensifica a partir da década de 1970, resultando principalmente da expulsão dos trabalhadores do campo em consequência da modernização agrícola. A população salta de 65 mil habitantes, em 1950, para cerca de 168 mil, em 2000, sendo 97,2\% urbana. No início deste século, ocorre a diversificação da economia, com a instalação de indústrias multinacionais na cidade, vinculadas ao agronegócio, além da dinamização do setor de serviços, sobretudo nas áreas de saúde e educação superior

A expansão urbana ocorre em todas as direções, porém evidencia o alongamento da ocupação através dos eixos viários principais, sentido noroeste (Pontão), sudoeste (Tio Hugo), sudeste (Marau) e nordeste (Coxilha). Aos caminhos primitivos, sobrepõe-se, a partir da década de 1970, um sistema rodoviário regional, composto pela BR 285 (norte) e pelas perimetrais sul e leste, conformando um anel viário, não inteiramente ocupado em seu interior, mas já apresentando, na década de 1980, extravasamento nas direções sudoeste (bairro Santa Marta), norte (COHAB José Alexandre Zacchia) e nordeste (bairro São José).

Do ponto de vista socioespacial, ocorre a consolidação do padrão de segregação centroperiferia, emergente na primeira metade do século XX. Paralelo à valorização e verticalização das áreas centrais, se agravam as carências das áreas periféricas. 0 déficit habitacional se amplia, as políticas habitacionais (insuficientes), presentes nas décadas de 1970 e 1980, sob financiamento federal do extinto Banco Nacional de Habitação, produzem conjuntos periféricos, a exemplo dos bairros Cohab I e II, setor oeste, e José Alexandre Zacchia, setor norte. Depois de um período de arrefecimento de investimentos em habitação social, nas décadas de 1990 e 2000, o programa federal Minha Casa Minha Vida - 
MCMV, instituído em 2009, dinamizou o setor da construção civil na cidade, no entanto, no campo da habitação de interesse social, para famílias de baixa renda, reproduziu o modelo de habitação periférica concentrado, sobretudo, na porção oeste da cidade, no setor Santa Martha, caracterizado, historicamente, por altos índices de vulnerabilidade social.

Em consequência desse processo, conforme demonstra a figura 2, a estrutura social, representada pela variável renda média, a partir de dados do IBGE (2010), revela uma gradação decrescente dos estratos sociais do centro para a periferia. Dentre os bairros consolidados de alta renda, caracterizados por grande homogeneidade social, estão a Vila Vergueiro, parcelas da Vila Rodrigues e Vila Annes, e o Bosque Lucas Araújo. A Vila Vergueiro, loteada na década de 1940, é o primeiro loteamento de Passo Fundo exclusivamente destinado às elites; os demais bairros de alta renda são ocupações mais tardias, descontínuos em relação ao centro. Destacam-se ainda alguns bairros em processo de valorização, como a Vila Fátima, no setor norte, nas proximidades da Vila Vergueiro, e o bairro São Cristóvão, no setor sudeste, tendo a Av. Presidente Vargas como principal eixo viário.

No outro extremo, a população de baixa renda se distribui por toda a periferia urbana, em bairros como José Alexandre Zacchia e Victor Issler, no setor norte, São Luiz Gonzaga, a leste, São José, a noroeste, Vila Planaltina, ao sul; Santa Martha, Donária, Integração e Prof. Schisler, a oeste. A formação desses setores resulta basicamente de três processos, que podem ocorrer simultaneamente, mas têm naturezas distintas, estando vinculados, no primeiro caso à produção privada de loteamentos; no segundo à produção de conjuntos habitacionais pelo Estado, e no terceiro às ocupações irregulares de áreas públicas ou privadas, com destaque à orla ferroviária, que cruza as porções leste e norte da cidade. 


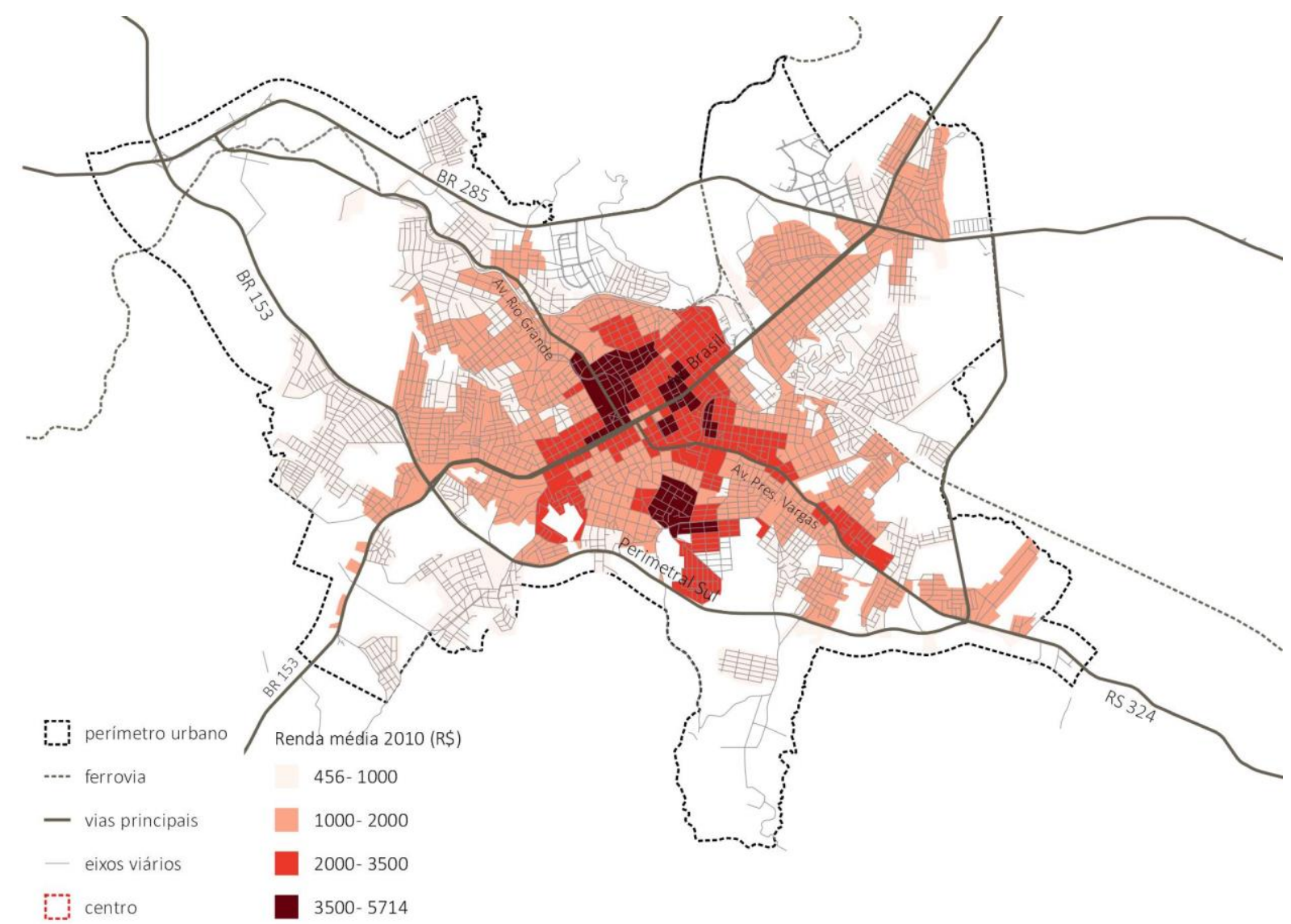

Passo Fundo: renda média (2010)

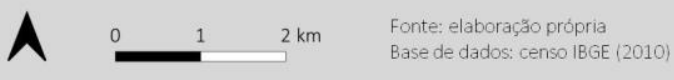

Figura 2 - Passo Fundo: renda média (2010)

Fonte: adaptado de Ferretto (2018)

\section{Reestruturação intraurbana}

A década de 2010 se caracteriza por algumas rupturas significativas nos processos de produção do espaço intraurbano de Passo Fundo. Ao passo que se observam continuidades nos processos de estruturação em curso, representadas pelo avanço da expansão horizontal periférica de baixa renda e agravamento do padrão de segregação centro-periferia, as rupturas, por sua vez, se explicitam através da emergência de novos produtos imobiliários em áreas periféricas.

A disseminação de condomínios horizontais fechados e bairros planejados remete a novos padrões de autossegregação das classes médias e de alta renda em áreas periféricas, tradicionalmente ocupadas pelos mais pobres. Esse processo, de ressignificação da periferia 
denota a complexificação da estrutura socioespacial intraurbana, indicando rupturas significativas com o período precedente, o que nos permite, a partir de Sposito (2013), reconhecer processos de reestruturação intraurbana em curso.

Considerando empreendimentos de caráter comercial, anunciados na mídia local, e já lançados, foram identificados cinco condomínios horizontais e quatro bairros planejados, localizados na figura 3. Os itens que seguem são direcionados à análise das especificidades desses dois grupos de empreendimentos, considerando aspectos quantitativos e qualitativos, com enfoque, sobretudo, em suas repercussões socioespaciais intraurbanas.

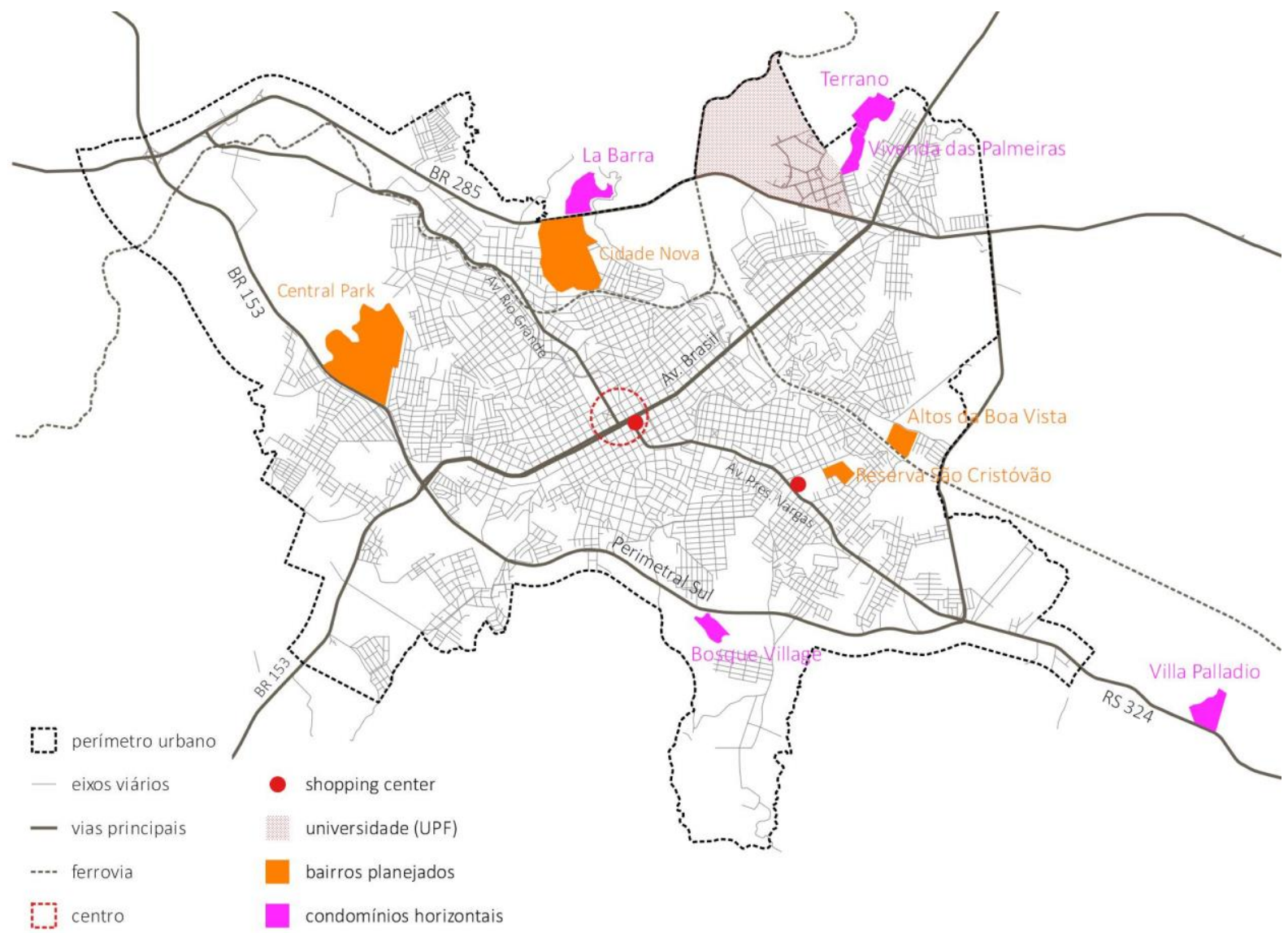

Passo Fundo: reestruturação intraurbana | 2020

Figura 3 - Passo Fundo: reesturutração intraurbana (2020)

Fonte: Elaborado pelo autor sobre mapa base da Prefeitura Municipal de Passo Fundo

\subsection{Condomínios horizontais}

A Os condomínios horizontais se disseminam na América Latina a partir da década de 1990, incluindo as cidades médias, sendo uma das feições mais significativas dos processos de 
autossegregação das camadas de alta renda em áreas periféricas. Neste texto, entende-se por "condomínios horizontais" os empreendimentos residenciais multifamiliares de acesso restrito, murados ou cercados, definidos por um conjunto de lotes que compartilham áreas comuns (vias, áreas livres, equipamentos) e têm acesso controlado. Essa denominação não se vincula aos estatutos jurídicos específicos dos empreendimentos estudados ${ }^{1}$, assim como a abordagem não engloba o pertinente debate em torno de sua (i)legalidade ${ }^{2}$.

A partir de pesquisa empírica, realizada por meio eletrônico, através de consulta a anúncios imobiliários, foram localizados 18 condomínios horizontais em Passo Fundo, de diferentes tamanhos, padrões e perfis socioeconômicos ${ }^{3}$. Levando-se em consideração critérios quantitativos (área total, número de lotes) e qualitativos (infraestrutura interna do condomínio, tamanho dos lotes, padrões construtivos das edificações), assim como as localizações, foi possível identificar três grupos de empreendimentos.

O primeiro grupo é definido por condomínios de casas populares implantados na periferia, na porção sudoeste da cidade, no setor urbano 4 Santa Martha, no âmbito do Programa Habitacional Minha Casa Minha Vida (PMCMV)5 ${ }^{5}$ e de acordo com Plano Urbanístico Local Região Sudoeste/Perimetral Sul $(2013)^{6}$. O segundo grupo de condomínios remete a empreendimentos de pequeno porte, com área máxima de dois hectares, e até 30 lotes, voltados às classes de média e média-alta renda, inseridos no tecido urbano consolidado,

\footnotetext{
${ }^{1}$ Em Passo Fundo, os condomínios horizontais são denominados "condomínios urbanísticos", definidos no Artigo 2ㅇ da Lei Complementar № 230/2009, que dispõe sobre o parcelamento do solo urbano no município, como "a divisão de gleba ou lote em unidades autônomas destinadas à edificação para fins residenciais, com áreas de uso comum dos condôminos".

${ }^{2}$ Sobre o tema, ver Freitas (2008) e Loyolla (2018).

3 Admite-se que esse número seja maior, uma vez que o levantamento considera somente os empreendimentos anunciados em sites de internet, pois não se obteve acesso aos decretos de aprovação emitidos pela Prefeitura Municipal de Passo Fundo.

${ }^{4} \mathrm{O}$ perímetro urbano de Passo Fundo é subdivido em 22 setores urbanos, segundo a Lei Complementar №131 (2004), cada setor urbano engloba uma série de bairros e vilas.

${ }^{5}$ Trata-se do empreendimento denominado Jardins Nativos, em implantação desde 2012 pela Construtora Priori, com sede na cidade. O empreendimento contempla 17 condomínios habitacionais com três tipologias: casas geminadas, casas isoladas e apartamentos. Dentre os condomínios horizontais, 8 são de casas geminadas, de 24 unidades cada, somando 192 unidades, enquadrados na faixa 1 do programa; 5 condomínios são de casas isoladas, com 23 unidades cada, perfazendo 115 unidades, enquadrados na faixa 2 do programa (Kalil e Gelpi, 2016).

6 Disponível em: <http://www.pmpf.rs.gov.br/servicos/geral/multimidia/PMSB-RELATORIO-SINTESE.pdf.>. Acesso em 31/07/2020.
} 
geralmente sem equipamentos de uso comum, construídos na década de $2010^{7}$. O terceiro grupo é constituído por condomínios de luxo implantados em áreas periféricas ainda não urbanizadas, empreendimentos amplamente divulgados na mídia local, caracterizados pela oferta de sistemas de vigilância e equipamentos e áreas de lazer de uso comum, como clubes, piscinas, quadras de esportes, pistas de caminhada e bosques. Com essas características foram identificados cinco empreendimentos, sendo quatro deles já habitados, (Vivenda das Palmeiras, Bosque Village, Villa Palladio, La Barra), lançados entre 2009 e 2012, e um quinto empreendimento, o condomínio Terrano, em fase de prélançamento desde 2019.

Destacam-se ainda dois condomínios que por suas especificidades não se enquadram em nenhum dos três grupos anteriormente citados, são eles os condomínios Morada Além do Horizonte e Conquista. O primeiro, localizado em zona rural do município, é pioneiro, inaugurado em 1984, na área do antigo balneário Chiaparini, sendo atualmente utilizado pela metade dos proprietários como segunda residência (ARESI; FIORESI, 2011); o segundo, localizado no setor São Cristóvão, foi implantado em área pública doada pela prefeitura municipal à Cooperativa Habitacional Conquista, formada por servidores da Brigada Militar, que vem sendo ocupado desde $2017^{8}$.

A totalidade dos condomínios identificados tem em comum a adoção de uma nova forma de morar, que na cidade se difunde somente na década corrente, pautada sobretudo nos anseios por segurança e na adoção de novos padrões de sociabilização em espaços intramuros. No entanto, do ponto de vista espacial, somente o terceiro grupo, dos condomínios de luxo periféricos, pode ser associado a processos de reestruturação intraurbana, uma vez que ressignificam áreas periféricas historicamente ocupadas pelos pobres, denotando rupturas nas lógicas precedentes de produção da cidade. Assim, interessa o aprofundamento desse grupo de empreendimentos, visando sobretudo compreender suas possíveis repercussões na estrutura socioespacial intraurbana.

\footnotetext{
${ }^{7}$ São exemplares desse grupo, os condomínios Gramado, Morada dos Pinhais, Piccola Città, Reserva do Bosque, Villa Veneto, Green Village, Village Petrópolis, Condado Vergueiro, Notre Dame, Attena Village e Altos da Annes.

${ }^{8}$ O projeto inclui dois condomínios horizontais, Conquista I (80 unidades), Conquista II (50 unidades) e um condomínio vertical, Conquista 3 (128 unidades), o último ainda não construído. Os condomínios horizontais, com lotes de $300 \mathrm{~m}^{2}$, não possuem equipamentos de uso comum e ocupam 6.8 ha.
} 
Os condomínios de luxo começam a aparecer na cidade a partir de 2009, sendo o Vivenda das Palmeiras o primeiro deles, localizado no setor São José, nas proximidades da Universidade de Passo Fundo (UPF); no ano seguinte, em 2010, são lançados os condomínios Boque Village e Villa Palladio, o primeiro localizado no setor Lucas Araújo, nas imediações do bairro nobre Bosque Lucas Araújo, junto à rodovia Perimetral Sul, e o segundo, em área rural, na porção sudoeste do município, às margens da RS 324 (KM 106), saída para Marau. Em seguida, em 2012, é lançado o condomínio La Barra, junto ao loteamento Cidade Nova, com acesso pela BR 285 (ver tabela 1 e figura 4). Em 2019, entra em fase de pré-lançamento o condomínio Terrano, vizinho ao condomínio Vivenda das Palmeiras, no setor São José.

Tabela 1: Passo Fundo - condomínios horizontais fechados (2020)

\begin{tabular}{|c|c|c|c|c|c|}
\hline \multicolumn{7}{|c|}{ Passo Fundo: condomínios fechados horizontais (2020) } \\
\hline empreendimento & lançamento & área total (ha) & $\mathrm{n}$ - de lotes & $\begin{array}{c}\text { área dos lotes } \\
\left(\mathrm{m}^{2}\right)\end{array}$ & setor urbano \\
\hline Vivenda das Palmeiras & 2009 & 15.7 & 149 & $400-550$ & São José \\
\hline Bosque Village & 2010 & 11.2 & 46 & $1568-4005$ & Lucas Araújo \\
\hline Villa Palladio & 2010 & 18.8 & 115 & $950-1000$ & zona rural (sudeste) \\
\hline La Barra & 2012 & 30 & 157 & $600-2376$ & Victor Issler \\
\hline Terrano & $2019 *$ & $* *$ & 402 & $240-476$ & São José \\
\hline * Data de pré lançamento do empreendimento & $* *$ dado indisponível & & \\
\hline
\end{tabular}

Fonte: Elaborado pelo autor 


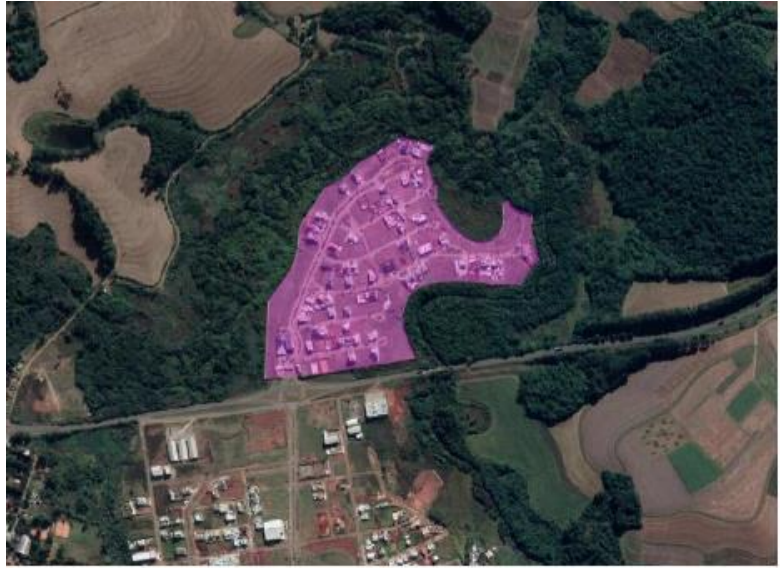

La Barra | setor Victor Issler

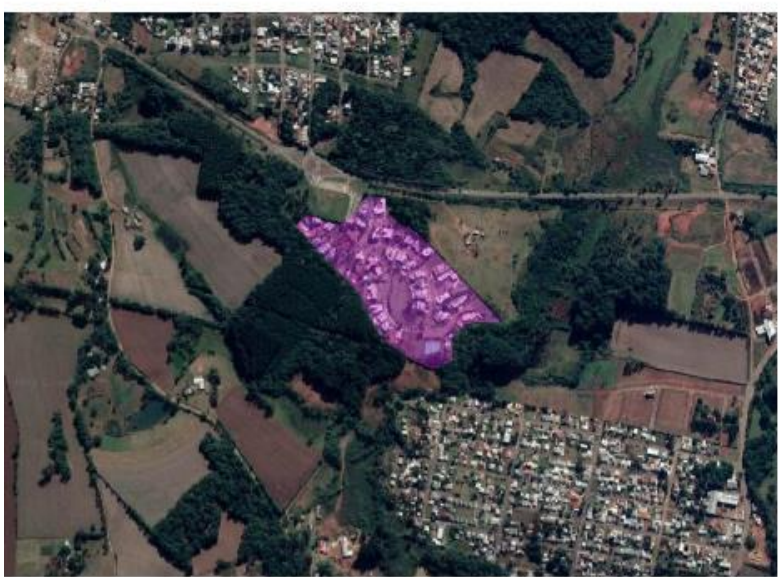

Bosque Village | setor Lucas Araújo

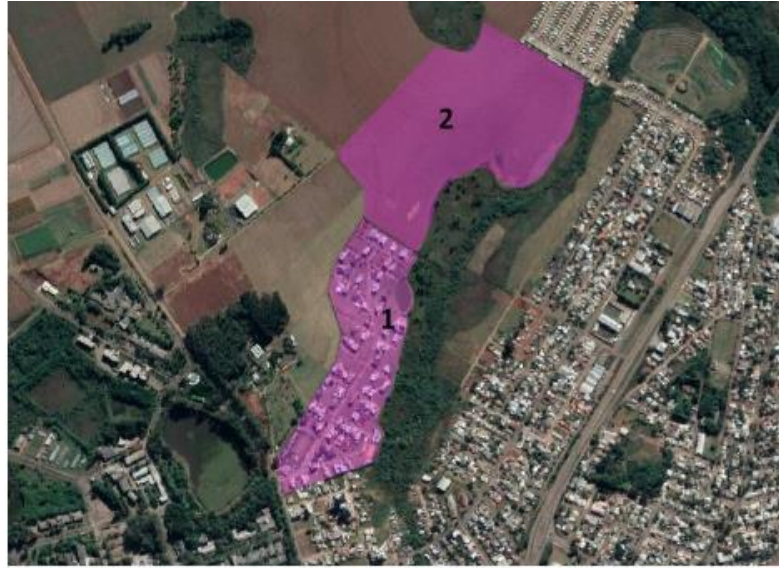

Vivenda das Palmeiras (1) e Terrano (2) | setor São José

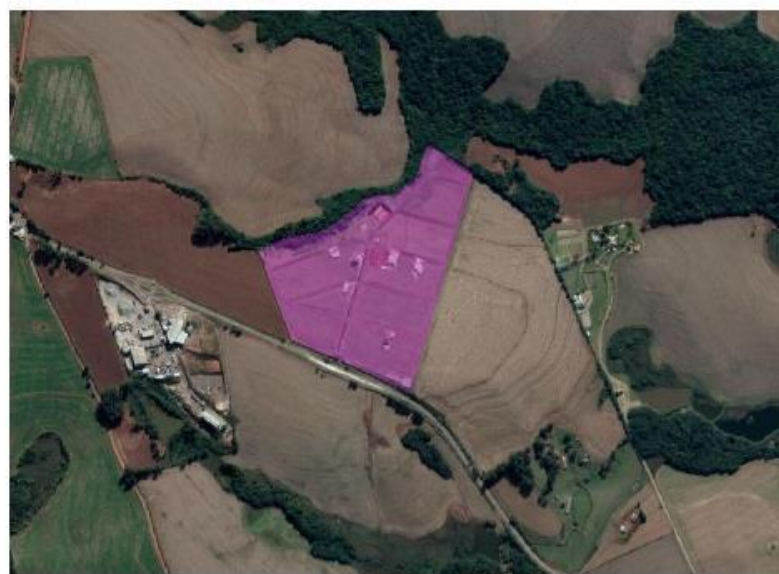

VIla Pal adio | área cural

Passo Fundo: condominíos horizontais | 2020

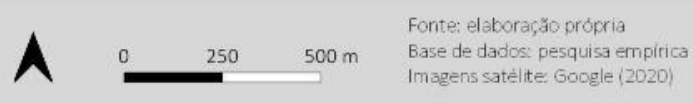

Figura 4 - Passo Fundo: condomínios horizontais (2020)

Fonte: Elaborado pelo autor, sobre imagem de satélite Google (2020)

Os empreendimentos têm área entre 11.2 e 30 ha, variando de 46 a 157 lotes, sendo o Bosque Village o menor, e o La Barra, o maior. Os tamanhos dos lotes variam entre 240 e $2.376 \mathrm{~m}^{2}$. Nos cinco casos, além dos lotes residenciais, estão presentes edifícios de uso comum, como clubes, salões de festas, além das áreas livres de lazer e prática esportiva.

A partir de consultas a anúncios imobiliários de imóveis à venda nos condomínios estudados, obtivemos uma aproximação das médias de preços do $\mathrm{m}^{2}$ de lotes sem edificações, e do $\mathrm{m}^{2}$ de área construída, de casas à venda ${ }^{9}$. A média de preços do $\mathrm{m}^{2}$ dos

\footnotetext{
${ }^{9}$ Ressalta-se que se trata de valores de referência com finalidade comparativa, não se constituindo propriamente uma pesquisa de mercado imobiliário, uma vez que não atende à amostragem e aos métodos estatísticos necessários. Os valores dos lotes foram obtidos a partir das médias de cinco anúncios, para cada
} 
lotes é de 522 reais $^{10}$, sendo mais alto no condomínio La Barra (815 reais), seguido do Vivenda das Palmeiras (587 reais), Bosque Villlage (428 reais) e Villa Palladio (258 reais). 0 valor médio do $\mathrm{m}^{2}$ construído é de 5.240 reais, atingindo 6.279 reais no Bosque Village, 5.148 reais no Vivenda das Palmeiras, e 4.300, no Villa Palladio.

Segundo pesquisa da Revista Exame ${ }^{11}$, em 2018, o preço do $\mathrm{m}^{2}$ construído de imóveis usados é de 4.414 reais na cidade, cerca de 16\% inferior à média dos condomínios. Comparativamente aos preços divulgados por bairros, os condomínios apresentam maior valorização em relação ao seu entorno imediato. $O$ preço do $\mathrm{m}^{2}$ no condomínio Vivenda das Palmeiras é cerca de $20 \%$ superior ao vizinho bairro São José, situação semelhante em relação ao condomínio Bosque Village e seu entorno, onde a diferença de preços se aproxima dos $30 \%$. O valor médio do $\mathrm{m}^{2}$ dos condomínios em questão se equipara aos valores do centro da cidade e dos bairros Cidade Nova, São Cristóvão e Vila Rodrigues, que estão entre 4.901 e 5.400 reais, ficando atrás somente dos bairros Vila Fátima e Vila Santa Terezinha, com oscilação entre 5.801 e 6.300 reais $0 \mathrm{~m}^{2}$, patamar que, se considerado isoladamente, o condomínio Bosque Village atinge.

Embora não se possa comprovar empiricamente neste estudo, a valorização imobiliária dos condomínios horizontais pressupõe altos índices de lucratividade em torno da conversão de áreas pouco valorizadas, de terra barata (urbana ou rural), em produtos imobiliários atrativos, com alto valor agregado.

Sob a ótica das estratégias de marketing do setor imobiliário, alguns pontos podem ser elencados como comuns aos cinco empreendimentos analisados: modernidade, exclusividade, segurança, acessibilidade e contato com a natureza. A ideia de modernidade é associada à suposta novidade que a vida em condomínios pode proporcionar, como uma espécie de superação da cidade existente; à esteira dessa novidade vem a noção de

condomínio, já os valores do $\mathrm{m}^{2}$ construído foram obtidos a partir dos anúncios de casas à venda, nos casos dos condomínios Bosque Village e Villa Palladio, somente uma unidade, no condomínio Vivenda das Palmeiras, a partir da média de cinco unidades, não localizou-se casas à venda no condomínio La Barra. Não foram encontrados valores de referência para o condomínio Terrano, em fase de pré-lançamento.

${ }^{10}$ Todos os valores citados na moeda brasileira (Real) podem ser convertidos para a moeda da União Europeia (Euro), tomando-se como referência a data de 30/10/2020, em que foram efetuados os levantamentos referentes aos preços dos imóveis em Passo Fundo. Nesta data, 1 real equivalia a 0,14930 euro (https://br.investing.com/currencies/eur-brl-converter), sendo, a título de exemplo, a média de preços do $\mathrm{m}^{2}$ dos lotes em condomínios horizontais na cidade, de 522 reais, equivalente a 77,93 euros.

${ }^{11}$ Guia de imóveis 2018 - edição 1161 (15/05/2018). Disponível em: < https://exame.com/revista-exame/sulrio-grande-do-sul/>. Acesso em 07/07/2020. 
exclusividade, como uma opção para poucos; a segurança, por sua vez, é garantida por muros e sistemas de vigilância com lugar de destaque nas propagandas, sendo um componente essencial dessa modalidade de empreendimentos; o fácil acesso ao centro da cidade, sempre por meio de transporte motorizado individual, é coberto pela acessibilidade ao sistema viário estrutural; e, por fim, a proximidade da natureza é sempre valorizada, seja a partir da pré-existência de fragmentos de mata nativa, seja resultante das intervenções projetadas.

Do ponto de vista espacial, analisando-se as localizações dos condomínios de luxo na cidade, têm-se como fator comum as localizações periféricas, em áreas não urbanizadas, próximas a bairros populares, e sobretudo às margens de rodovias, que garantem acesso fácil à toda a cidade, e sobretudo ao centro. Algumas especificidades, no entanto, podem ser destacadas: os condomínios La Barra, Vivenda das Palmeiras e Terrano, situados na porção norte nordeste da cidade, têm como diferencial a proximidade da UPF, equipamento de abrangência regional; por outro lado, também é valorizada a proximidade de bairros de prestígio social, no caso do Bosque Village, na porção sul, o bairro Bosque Lucas Araújo, ao qual o condomínio faz alusão no nome, e no caso do condomínio La Barra, o bairro planejado Cidade Nova (objeto de discussão no próximo item), e as vilas Fátima e Vergueiro. Por sua vez, o Villa Palladio, situado em área rural, na porção sudeste do município, apresenta-se como o caso mais desvinculado de referenciais urbanos, conectando-se à cidade pela RS 324, sendo também aquele com menor índice de ocupação, com menos de uma dezena dos 115 lotes disponíveis ocupados ${ }^{12}$, sem levar em consideração o condomínio Terrano, em pré-lançamento e ainda não ocupado.

Ainda que os encartes publicitários valorizem os referenciais urbanos de interesse, o que se percebe, do ponto de vista urbanístico, são novos processos de autossegregação das classes de alta renda, que embora caracterizados pela aproximação física de setores populares, ocasionam maior distanciamento social, imprimido por barreiras físicas incisivas e por sofisticados sistemas de segurança. Com exceção do condomínio Villa Palladio, ainda isolado em área rural, é possível perceber, nos outros quatro casos, a proximidade de bairros pobres, de alta vulnerabilidade social, a exemplo do bairro São José, vizinho dos

\footnotetext{
12 Segundo contagem sobre imagem de satélite disponibilizado pelo Google, de 9/03/2020.
} 
condomínios Vivenda das Palmeiras e Terrano, ou da Vila Planaltina, vizinha do condomínio Bosque Village.

O condomínio La Barra apresenta uma situação simbólica nesse sentido, pois reproduz uma condição de segregação extrema, similar ao que ocorre com o bairro José Alexandre Zacchia, também implantado às margens da BR 285, descontínuo à mancha urbana (figura 5). Enquanto o La Barra exprime a possibilidade de autossegregação das classes de alta renda, o Zacchia evidencia processos de segregação imposta remanescente da década de 1980, quando o conjunto habitacional Pró-Morar, executado pela COHAB, com recursos do BNH, foi criado a partir de 620 unidades embriões para famílias com renda de até 3 salários mínimos $^{13}$, jamais sendo atendido plenamente por infraestrutura urbana adequada, e tendo acumulado vulnerabilidades socias ao longo do tempo. Se a essência do processo é semelhante, a dispersão da elite pela periferia é novidade, evidenciando, portanto, rupturas com as lógicas precedentes e a emergência de processos de reestruturação em curso.

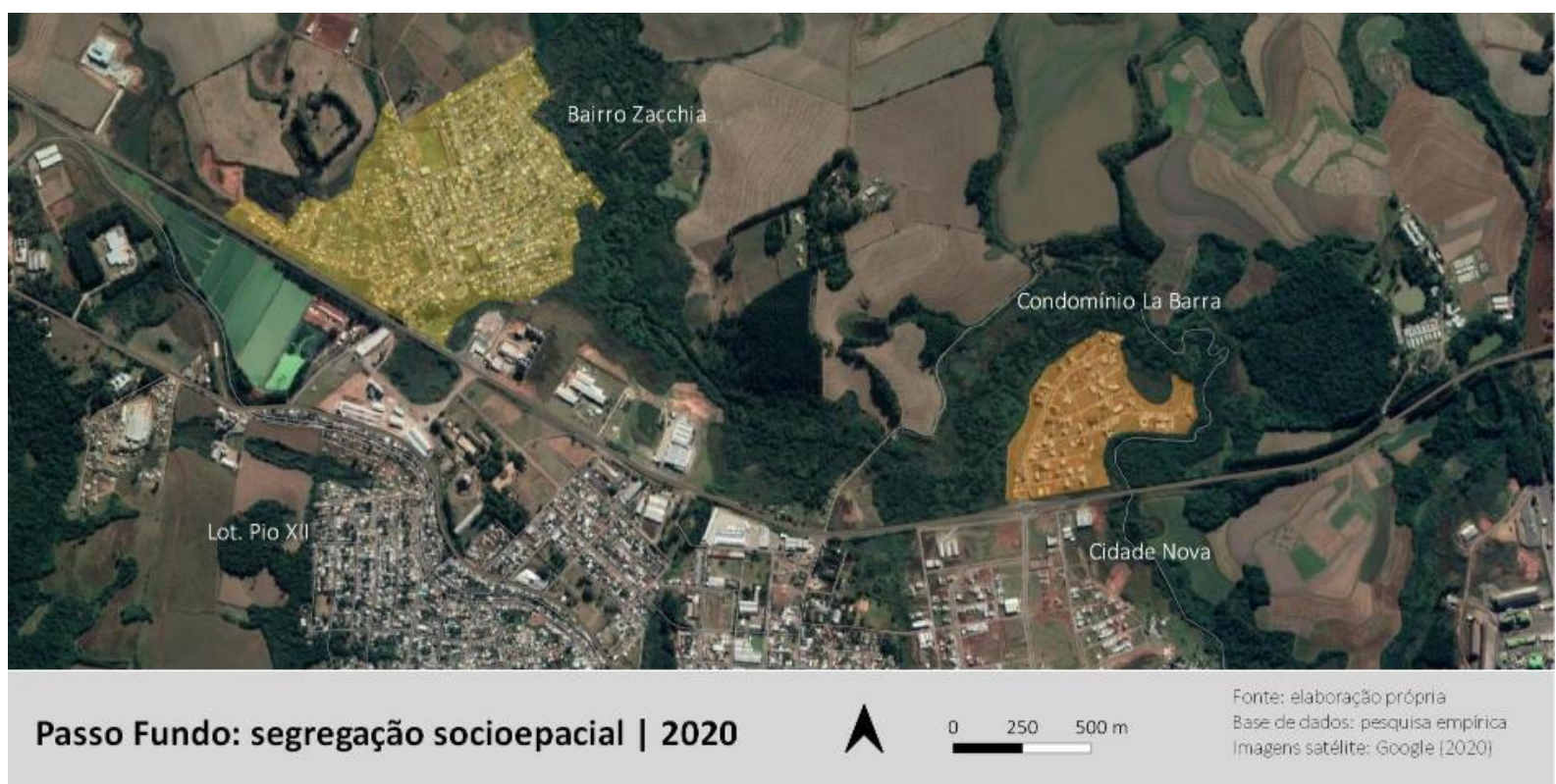

Figura 5 - Passo Fundo: condomínios horizontais (2020)

Fonte: Elaborado pelo autor, sobre imagem de satélite Google (2020)

\footnotetext{
${ }^{13}$ Em 2020, o valor do salário mínimo corresponde a 1.045 reais, regulamentado na Lei 14.013/20.
} 


\subsection{Bairros planejados}

A proposta de bairros planejados não é nova no Brasil, pois desde as primeiras décadas do século XX têm prestígio os bairros jardins, inaugurados pela Companhia City na cidade de São Paulo, à semelhança dos subúrbios jardins ingleses e americanos, que significaram uma espécie de distorção dos ideais de cidade jardim, formuladas por Ebenezer Howard. Os bairros jardins constituíram-se como áreas monofuncionais, com baixas densidades habitacionais e construtivas, abundância de áreas verdes e promoção do uso do automóvel. Esse modelo se consolidou e se proliferou por diversas cidades brasileiras, direcionado às elites locais e associado à qualidade de vida, e de certo modo, dialogando com os ideais da cidade moderna.

Nas últimas décadas, no entanto, novos paradigmas têm balizado as práticas de planejamento urbano, como uma reação ao urbanismo modernista que promoveu a cidade dispersa e monofuncional. A partir da década de 1980, em linhas gerais, enfatiza-se a necessidade de cidades mais sustentáveis, do ponto de vista social, econômico e ambiental. As discussões em torno da sustentabilidade urbana se ancoram em pressupostos, expressos teoricamente, dentre os quais se destacam os ideais do Novo Urbanismo ou New Urbanismo, do modelo de Cidade Compacta e das Smart Cities. Embora dotados de especificidades, esses movimentos estabelecem novos paradigmas, amplamente aceitos atualmente, pautados sobretudo na diversidade de usos, no adensamento construtivo e habitacional, na compacidade da mancha urbana, na priorização do pedestre e do transporte público, e na utilização racional dos recursos naturais. Em geral, os bairros planejados incorporam esse discurso, do ponto de comercial, sendo vendidos como uma alternativa de desenvolvimento urbano sustentável, associado a melhorias de qualidade de vida nas cidades, embora, em diversas situações reproduzam também padrões de segregação e não se conectem de forma efetiva à cidade e sobretudo ao entorno em que se inserem.

Em Passo Fundo, esse processo está em curso, nesta década foram lançados quatro bairros planejados, sendo o pioneiro o bairro Cidade Nova, de 2011, seguido dos bairros Alto da Boa Vista (2017), Reserva São Cristóvão (2018), e mais recentemente, do bairro Central Park, lançado em 2019, com previsão de entrega dos lotes com infraestrutura no final de 2021. 
Tabela 2: Passo Fundo - bairros planejados (2020)

\begin{tabular}{|l|c|c|c|c|l|}
\hline \multicolumn{7}{|c|}{ Passo Fundo: bairros planejados (2020) } \\
\hline \multicolumn{1}{|c|}{ empreendimento } & lançamento & área total (ha) & $\begin{array}{c}\text { no de } \\
\text { lotes }\end{array}$ & $\begin{array}{c}\text { área dos lotes } \\
\left(\mathrm{m}^{2}\right)\end{array}$ & \multicolumn{1}{c|}{ setor urbano } \\
\hline Cidade Nova & 2011 & 81 & 702 & $300-1757$ & Victor Issler \\
\hline Alto da Boa Vista & 2017 & $13^{*}$ & 200 & $287.5-420$ & São Luiz Gonzaga \\
\hline Reserva São Cristóvão & 2018 & 10 & 151 & $* * *$ & São Cristóvão \\
\hline Central Park & 2019 & $147^{* *}$ & $283^{* *}$ & $* * *$ & Nenê Graeff \\
\hline * área aproximada I ** números correspondentes à primeira fase do empreendimento. | *** dados indisponíveis \\
\hline
\end{tabular}

Fonte: Elaborado pelo autor

Analisando-se as características dos quatro empreendimentos, é possível reconhecer duas situações distintas, em função do porte, programa de usos e inserção urbana (tabela 2 e figura 6).

Os bairros Cidade Nova, com 81 ha e 702 lotes, e Central Park, com área total de 147 ha, sendo a primeira fase correspondente a 20 ha e 283 lotes, caracterizam-se como empreendimentos de grande porte voltados à urbanização de glebas vazias em áreas periféricas, respectivamente, nas porções norte e oeste da cidade. Já os bairros Altos da Boa Vista (13 ha - 200 lotes) e Reserva São Cristóvão (10 ha - 151 lotes) promovem a ocupação de vazios urbanos inseridos na mancha urbana, nos dois casos, na porção leste da cidade. 


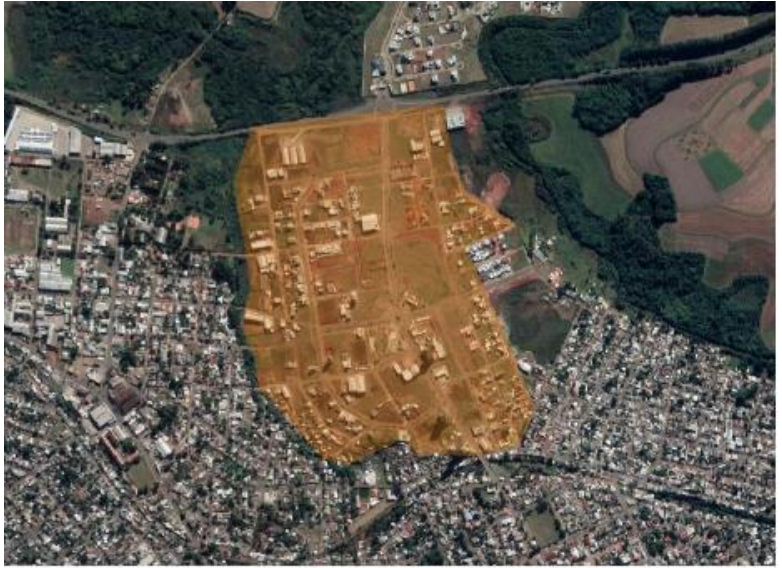

Cidade Nova | setor Victor Issler

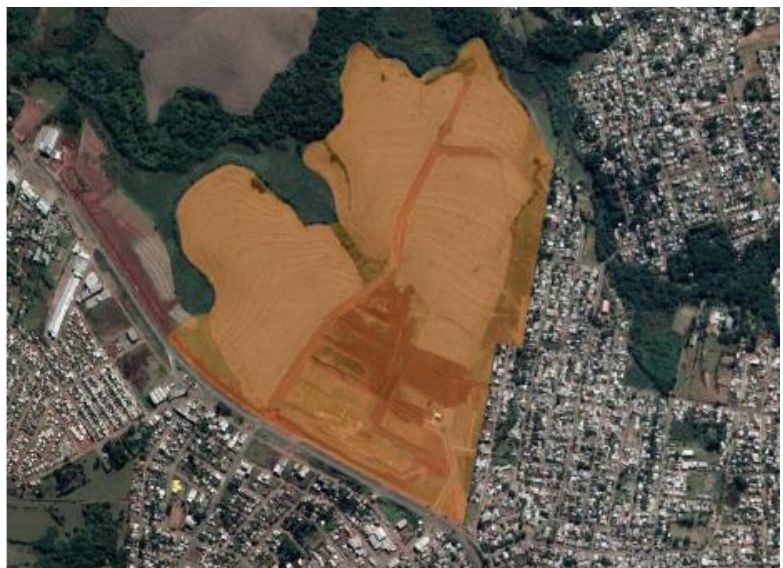

Central Park | setor Nenê Graeff

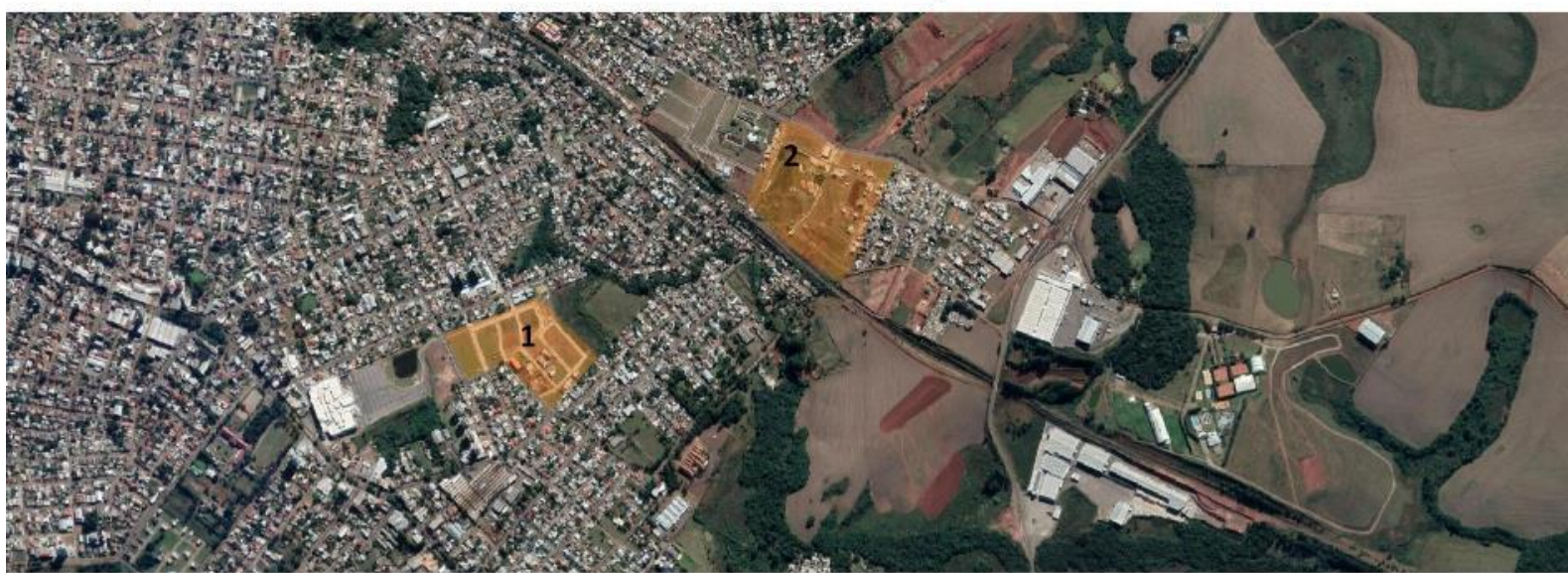

Reserva Săo Cristóvão (1)- setor São Cristóvão| Al tos da Boa Vista (2)-setor São Luiz Gonzaga

Passo Fundo: bairros planejados | 2020

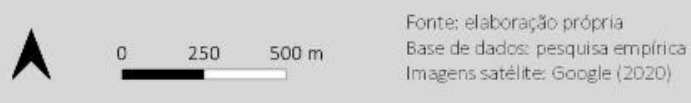

Figura 6 - Passo Fundo: condomínios horizontais (2020)

Fonte: elaboração própria sobre imagem de satélite Google (2020)

Do ponto de vista do programa dos empreendimentos, os anúncios do bairro Central Park mencionam uso misto, porém sem maiores especificações; no bairro Altos da Boa Vista, aproximadamente $20 \%$ dos lote são comerciais; já o Reserva São Cristóvão é exclusivamente residencial; o bairro Cidade Nova, por sua vez, apresenta-se como o mais diversificado em termos de usos, contemplando comércio e serviços (com área reservada para um shopping center), uso logístico, às margens da BR 285, e o uso residencial, unifamiliar e multifamiliar, horizontal e vertical.

As estratégias de marketing dos empreendimentos enfatizam a qualidade de vida, o fácil acesso ao centro da cidade e, amparados nos preceitos da cidade compacta, os empreendimentos que possuem uso misto destacam as facilidades de acesso ao comércio e 
serviços no próprio bairro. No âmbito do desenho urbano, sublinha-se a priorização dos pedestres e ciclistas, com vias compartilhadas, calçadas amplas, pistas de caminhada e ciclovias; os espaços públicos, de convívio e lazer, como praças e parques, quadras esportivas, academias ao ar livre, comparecem nos projetos valorizando as áreas de convívio. Aspectos de infraestrutura urbana (drenagem, pavimentação, iluminação) são mencionados, além de diferenciais como acesso à rede wi-fi de internet nos espaços abertos de uso comum. Do ponto de vista da segurança, menciona-se o monitoramento dos bairros por câmeras.

Relativo ao perfil socioeconômico dos empreendimentos, a partir de pesquisa por meio eletrônico em anúncios imobiliários, seguindo a mesma metodologia dos levantamentos referentes aos condomínios horizontais, obteve-se a média de valor do $\mathrm{m}^{2}$ dos lotes nos quatro empreendimentos, observando-se o maior custo no bairro Reserva São Cristóvão (932.2 reais $\left./ \mathrm{m}^{2}\right)$, seguido pelo Cidade Nova $\left(646,2 / \mathrm{m}^{2}\right)$; e com valores muito similares, em média 380 reais o $\mathrm{m}^{2}$, aparecem os bairros Central Park e Alto da Boa Vista.

A variação de valores se explica pela dinâmica das localizações intraurbanas, dos níveis de acesso à infraestrutura e equipamentos, assim como pelo prestígio social dos bairros. $\mathrm{O}$ elevado preço da terra no Reserva São Cristóvão se justifica pela inserção no bairro São Cristóvão, tradicional bairro de classe média em crescente valorização imobiliária, potencializada pela relação de vizinhança com o Shopping Passo Fundo, inaugurado em 2018. O empreendimento Altos da Boa Vista, embora situado somente a $1 \mathrm{~km}$ (em linha reta) do Reserva São Cristóvão, apresenta outro contexto urbano, junto ao bairro Luiz Gonzaga, predominantemente de baixa renda, às margens da ferrovia, em área em processo de consolidação.

Dentre os maiores empreendimentos, o bairro Cidade Nova já apresenta certo grau de consolidação na cidade, com a maioria dos lotes vendidos ${ }^{14}$, infraestrutura completa e diversas edificações construídas, de usos variados; o bairro Central Park, em fase de lançamento, situado na periferia oeste da cidade, não apresenta diferenciais locacionais,

\footnotetext{
14 Segundo tabela de preços veiculada pelo site da construtora Bolsa, responsável pelo empreendimento, em 21/07/2020, há somente 20 lotes à venda, menos de 3\% do total. Essa informação pode ser acessada pelo link: http://www.cidadenovapf.com.br/application/resources/pdf/Tabela\%20Cidade\%20Nova_16_07_2020.pdf
} 
pelo contrário, sendo a dinamização da região dependente do sucesso do próprio empreendimento.

\section{Considerações finais}

Esse texto, cujo objetivo central foi discutir os processos de reestruturação intraurbana em curso na cidade de Passo Fundo, através da disseminação de novos produtos imobiliários, permite reflexões finais de duas ordens, primeiro, em caráter de síntese, em torno dos fatos demonstrados, segundo, a partir de algumas hipóteses, a serem problematizadas em outros estudos, sobretudo a partir da observação empírica ao longo dos próximos anos.

Conforme evidencia a abordagem empírico-quantitativa, os condomínios fechados horizontais e os bairros planejados, introduzidos na cidade na década de 2010 , seguem em ascensão, atendendo a uma demanda solvável, e perpassando a severa crise econômica dos últimos anos.

A boa aceitação dos novos produtos imobiliários reproduz uma dinâmica recorrente em diversas cidades médias, norteada pela acumulação capitalista e ligada ao setor imobiliário. Do ponto de vista urbanístico, os condomínios horizontais trazem maior novidade, pois estabelecem-se como espaços desconexos à cidade, dotados de barreiras físicas, onde é marcante a ideia de exclusividade, enquanto os bairros planejados apresentam maior integração ao entorno em que se inserem, se assemelhando aos tradicionais loteamentos, mesmo que acrescidos de alguns equipamentos e dotados de sistemas de segurança.

O sucesso dos condomínios horizontais revela a tendência crescente de negação da cidade existente, que embora encontre bases materiais nos problemas urbanos, sobretudo na violência, se ancora, fundamentalmente, na aversão à diversidade, traduzida espacialmente em processos de segregação. Assim, os produtos imobiliários, essenciais à reprodução capitalista, encontram nos valores da sociedade a pré-disposição à sua aceitação.

Analisando-se a inserção espacial dos empreendimentos na estrutura intraurbana de Passo Fundo, foi possível identificar um padrão predominantemente periférico, nas duas tipologias estudadas. Dentre os cinco condomínios de alta renda identificados, três estão concentrados na porção nordeste da cidade (La Barra, Vivenda das Palmeiras e Terrano), 
nas proximidades da Universidade de Passo Fundo (UPF), com fácil acesso à BR 285, o quarto exemplar, o condomínio Bosque Village, está na porção sul da cidade, junto à rodovia Perimetral Sul, por fim, o condomínio Villa Palladio situa-se em área rural, na porção nordeste do município, às margens da RS 324. Dentre os bairros planejados, identificou-se duas situações, empreendimentos de grande extensão territorial (Cidade Nova e Central Park) ocupando glebas vazias em áreas periféricas, e empreendimentos de menor porte (Reserva São Cristóvão e Altos da Boa Vista) implantados em áreas mais consolidadas.

Relativo aos processos de reestruturação intraurbana, que de alguma forma rompem com as lógicas precedentes de produção do espaço urbano, dois fatores podem ser destacados: primeiro, a ocorrência de condomínios de alta renda em áreas periféricas, tradicionalmente ocupadas pela população de baixa renda, configurando novos processos de autossegregação, que embora diminuam a distância física entre as classes sociais, exacerbam o distanciamento social através de barreiras física; segundo, a ocorrência de bairros planejados, também em áreas periféricas, aventando a possibilidade de formação de novas centralidade, nos empreendimentos de usos misto, situação com maior potencial no bairro Cidade Nova.

À medida que se afirmam os processos de reestruturação em curso, revelando a complexificação da estrutura socioespacial intraurbana, tem-se certa indefinição no que diz respeito à transição do padrão de segregação centro-periferia para a segregação das classes de alta renda por setores ou regiões da cidade. Essa questão se coloca com base nos estudos de Villaça (2001) sobre os processos de segregação em áreas metropolitanas brasileiras, e na observação de diversas cidades médias, que demonstram, respectivamente, os processos históricos de constituição de setores urbanos privilegiados, a exemplo do setor sudoeste de São Paulo, da zona sul de Porto Alegre, ou dos setores leste de cidades médias gaúchas como Santa Maria ou Pelotas, em que esse processo já é mais evidente.

No caso de Passo Fundo, têm-se por hipótese que a zona norte da cidade apresenta maior potencial à constituição de um setor urbano predominantemente ocupado pelas classes de alta renda, a ser gradativamente dotado de equipamentos, comércios e serviços capazes de configurar uma nova centralidade intraurbana. Associam-se, nesse setor, a implantação 
concomitante do bairro Cidade Nova e do condomínio La Barra à proximidade de bairros prestigiados como a Vila Fátima e a Vila Vergueiro, conformando assim um eixo de valorização imobiliária que se estende até o centro da cidade. Tomando-se o bairro Cidade Nova como centralidade dessa transformação, na direção leste, em um percurso de cerca de $4 \mathrm{~km}$ pela BR 285, situa-se a Universidade de Passo Fundo (UPF), ladeada por dois condomínios horizontais, o Vivenda das Palmeiras e o Terrano.

Evidentemente que essa hipótese não exclui o desenvolvimento e valorização de outros setores urbanos, a exemplo do bairro São Cristóvão, na porção sudeste, a partir da implantação do Shopping Passo Fundo, do bairro Reserva São Cristóvão, abarcando também o processo de verticalização ao longo da Avenida Presidente Vargas; da zona oeste, a partir do bairro planejado Central Park; ou ainda da zona sul, em torno do Bosque Lucas Araújo e nas proximidades do condomínio Bosque Village. No entanto, a zona norte da cidade reúne as condições necessárias ao desenvolvimento de uma nova expressão da centralidade intraurbana, constituída por setores de média e alta renda, com possibilidade de extensão até à UPF, e com a ocupação de glebas vazias.

A possível associação dos processos de autossegregação das classes de alta renda à formação de novas centralidades denotaria a emergência de processos de fragmentação socioespacial, segundo Sposito e Goés (2013), posteriores e mais complexos que a segregação, pois extrapolam o uso residencial, envolvendo a existência de policentralidades, a conformação de territórios descontínuos e a ocorrência de contiguidade sem continuidade.

\section{Referências}

Aresi, C.; Fioreze, Z. (2011). Condomínio Horizontal Morada Além do Horizonte: um lugar alternativo para moradia. Boletim Gaúcho de Geografia. 37, 141-150. Disponível em https://seer.ufrgs.br/bgg/article/viewFile/37369/24128

Carlos, A. F. (2015). A condição espacial. (2a ed.). São Paulo: Contexto.

Corrêa, R. L. (2007). Construindo o conceito de cidade média. In: M. E. B. Sposito (Org.), Cidades Médias: espaços em transição. (pp. 23-34). São Paulo: Expressão Popular.

Corrêa, R. L. (2010). Inovações espaciais urbanas - algumas reflexões. Cidades. 7, (11), 151-162. Disponível em https://revista.fct.unesp.br/index.php/revistacidades/article/view/528/559 
Corrêa, R. L. (2013). Segregação residencial: classes sociais e espaço urbano. In: P. A. Vasconcelos, R. L. Corrêa \& S. M. Pintaudi (Orgs.). A cidade contemporânea: segregação socioespacial. (pp. 39-60). São Paulo: Editora Contexto.

Dal'moro, S. \& Ruckert, A. A. (2004). A agricultura no processo de desenvolvimento do Planalto Médio riograndense. In: A. M. R. da Silva. Estudos de geografia regional: o urbano, o rural e o rurbano na região de Passo Fundo (pp. 26-68). Passo Fundo: EDUPF.

Ferretto, D. (2012). Passo Fundo: estruturação urbana de uma cidade média gaúcha (Dissertação de Mestrado), Universidade de São Paulo, Programa de Pós-Graduação em Arquitetura e Urbanismo, São Paulo. doi: 10.11606/D.16.2012.tde-17072012-143123

Ferretto, D. (2018). Segregação socioespacial em cidades médias gaúchas: Caxias do Sul, Passo Fundo, Pelotas e Santa Maria (Tese de Doutorado), Universidade de São Paulo, Programa de Pós-Graduação em Arquitetura e Urbanismo, São Paulo. doi: 10.11606/T.16.2019.TDE-19122018-172558

Freitas, E. L. H. (2008). Loteamentos fechados (Tese de Doutorado), Universidade de São Paulo, Programa de Pós-Graduação em Arquitetura e Urbanismo, Universidade de São Paulo, São Paulo. doi: 10.11606/T.16.2008.tde-18012010-230029

IBGE, Instituto Brasileiro de Geografia e Estatística (2008). Região de influência das cidades. Rio de Janeiro: IBGE/MPOG. Disponível em https://biblioteca.ibge.gov.br/visualizacao/livros/liv40677.pdf

Kalil, R. M. L.; Gelpi, A. (2016, junho). Habitação e morfologia urbana: criando novas paisagens. Anais do VIII Seminario Internacional de Investigación en Urbanismo. Barcelona-Balneário Camboriú. Disponível em https://upcommons.upc.edu/bitstream/handle/2117/100307/123CAM_KalilGelpi.pdf

Leite, C. R. (2013). Dinâmica imobiliária e espacial no Aglomerado urbano não metropolitano de Gramado e Canela: reflexos da produção de condomínios urbanísticos e loteamentos fechados. (Dissertação de Mestrado), Universidade de Santa Cruz do Sul, Programa de Pós-Graduação em Desenvolvimento Regional, Santa Cruz do Sul.

Loyolla, L. C. (2018). Reflexões sobre os Possíveis Impactos da Lei Federal 13.465/2017 nos Sistemas de Espaços Livres das Cidades Brasileiras. In Anais, XIII Colóquio QUAPA SEL, Santa Maria. Disponível em http://quapa.fau.usp.br/wordpress/wp-content/uploads/2018/12/ANAIS-XIII-COLO\%CC\%81QUIO-QUAPASELparte-1.pdf

Marques, E. (2005). Elementos conceituais da segregação, da pobreza urbana e da ação do Estado. In: E. Marques \& H. Torres (Orgs.) São Paulo, segregação, pobreza e desigualdades sociais (pp. 19-56). São Paulo: Senac.

Pohl, C. F. (2015). Loteamentos e condomínios fechados na cidade média de Santa Cruz do Sul - RS: uma análise sobre a constituição das áreas verdes. (Dissertação de Mestrado), Universidade de Santa Cruz do Sul, Programa de Pós-Graduação em Desenvolvimento Regional, Santa Cruz do Sul.

Sabatini, F. (2003). La segregación social del espacio en las ciudades de América Latina. Banco Interamericano de Desarollo. Disponível em https://publications.iadb.org/es/la-segregacion-social-del-espacio-en-lasciudades-de-america-latina

Sobarzo, O. (2010). Passo Fundo: cidade média com funções comerciais, de serviços e de apoio ao agronegócio. In: M. E. B. Sposito, D. Elias \& B. R. Soares (Orgs.). Agentes econômicos e reestruturação urbana e regional: Passo Fundo e Mossoró. São Paulo: Expressão Popular, pp. 29-100.

Spinelli, J. (2015). Mercado imobiliário e reestruturação do espaço urbano em Passo Fundo - RS. Porto Alegre (Tese de Doutorado), Universidade Federal do Rio Grande do Sul, Programa de Pós-Graduação em Geografia, Porto Alegre. Disponível em https://lume.ufrgs.br/handle/10183/128037

Sposito, M. E. B. (Ed.) (2007). Cidades Médias: espaços em transição. São Paulo: Expressão Popular.

Sposito, M. E. B. (2013). Segregação socioespacial e centralidade urbana. In: P. A. Vasconcelos, R. L. Corrêa \& S. M. Pintaudi (Orgs.). A cidade contemporânea: segregação socioespacial. (pp. 61-94). São Paulo: Editora Contexto. 
Sposito, M. E. B. \& Góes, E. M. (2013). Espaços fechados e cidades: insegurança urbana e fragmentação socioespacial. Presidente Prudente: Editora Unesp.

Sposito, M. E. \& Maia D. S. (Orgs.) (2016). Agentes econômicos e reestruturação urbana e regional: Chapecó e Dourados. São Paulo: Expressão Popular.

Sposito, M. E. B.; Elias, D.; Soares, B. R. (Orgs.) (2013). Agentes econômicos e reestruturação urbana e regional: Campina Grande e Londrina. São Paulo: Expressão Popular.

Sposito, M. E. B.; Elias, D.; Soares, B. R. (Orgs.) (2012). Agentes econômicos e reestruturação urbana e regional: Chillán e Marília. São Paulo: Expressão Popular.

Sposito, M. E. B.; Elias, D.; Soares, B. R. (Orgs.) (2015). Agentes econômicos e reestruturação urbana e regional: Marabá e Los Ángeles. São Paulo: Expressão Popular.

Sposito, M. E. B.; Elias, D.; Soares, B. R. (Orgs.) (2010). Agentes econômicos e reestruturação urbana e regional: Passo Fundo e Mossoró. São Paulo: Expressão Popular.

Sposito, M. E. B.; Elias, D.; Soares, B. R. (Orgs.) (2010 a). Agentes econômicos e reestruturação urbana e regional: Tandil e Uberlândia. São Paulo: Expressão Popular.

Rocha, L. (2011). O padrão locacional da estrutura social: segregação residencial em Santa Maria - RS. (Tese de Doutorado), Universidade Federal do Santa Catarina, Programa de Pós-Graduação em Geografia, Florianópolis.

Souza, M. B. (2013). Urbanização e segregação socioespacial na região do litoral norte do Rio Grande do Sul : uma análise da expansão e da (i)legalidade dos condomínios horizontais residenciais. (Dissertação de Mestrado), Universidade de Santa Cruz do Sul, Programa de Pós-Graduação em Desenvolvimento Regional, Santa Cruz do Sul.

Tedesco, J. C. \& Sander, R. (2005). Madeireiros, comerciantes e granjeiros: lógicas e contradições no processo de desenvolvimento socioeconômico de Passo Fundo (1900-1960). (2a ed.). Passo Fundo: EDUPF.

Vieira, S. G. (2005). A cidade fragmentada. Pelotas: Editora da UFPel.

Villaça, F. (2001). Espaço intra-urbano no Brasil. (2. ed.). São Paulo: Studio Nobel, FAPESP, Lincoln Institute. 